\title{
Comparative Structural Analysis of Biarylphosphine Ligands in Arylpal- ladium Bromide and Malonate Complexes
}

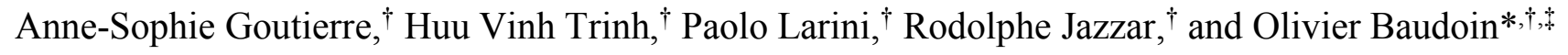 \\ 'Université Claude Bernard Lyon 1, CNRS UMR 5246 - Institut de Chimie et Biochimie Moléculaires et Supramoléculaires, \\ CPE Lyon, 43 Boulevard du 11 Novembre 1918, 69622 Villeurbanne, France. \\ ${ }^{*}$ Current address: Department of Chemistry, University of Basel, St. Johanns-Ring 19, CH-4056 Basel, Switzerland. \\ Supporting Information Placeholder
}

\begin{abstract}
The substitution of biarylphosphine ligands was shown to have a marked impact on the $\alpha / \beta$ selectivity of the arylation of ester enolates. To get further insight into this effect, the solid-state structures of arylpalladium bromide and malonate complexes with four different biarylphosphine ligands were obtained by $\mathrm{X}$-ray diffraction analysis. Structural differences were not very pronounced except for the conformationally restricted CPhos ligand, which showed a bidentate coordination mode in the oxidative addition complex, whereas the other ligands form dimeric species.
\end{abstract}

\section{INTRODUCTION}

The achievement of catalyst-controlled site-selectivity in catalytic transformations is a topic of increasing interest. ${ }^{1}$ However, the rational design of selective catalysts is often hampered by a lack of precise information on substrate-catalyst interactions during the selectivitydetermining step(s). We have recently developed a Pdcatalyzed migrative arylation of ester enolates ${ }^{2 a-c}$ and silyl ketene acetals, ${ }^{2 \mathrm{~d}}$ which allows to functionalize remote $\mathrm{C}-\mathrm{H}$ bonds of linear alkyl chains of esters. In this process, the arylation selectivity was shown to be both ligand- and substrate-controlled (Scheme 1). In particular, by testing a number of analogous biarylphosphine ligands on the arylation of isobutyric ester enolates $\left(\mathrm{R}^{1}=\right.$ $\mathrm{Me}$ ), we found that the substitution pattern of the former had a great influence on the arylation selectivity. ${ }^{2 b}$ Previous studies from Barder and Buchwald demonstrated the effect of binding modes and conformations of biarylphosphine ligands on elementary steps of various cross-coupling reactions. ${ }^{3}$ Such effects are likely to operate as well in migrative cross-coupling reactions, hence a better understanding thereof should have important implications for the development of new variants. ${ }^{4-5}$ Herein, we describe a structural study of model biarylphosphine-arylpalladium bromide and malonate complexes, which represents a first step toward this goal.

\section{Scheme 1. $\alpha$ - vs. $\beta$-Arylation of Ester Enolates}

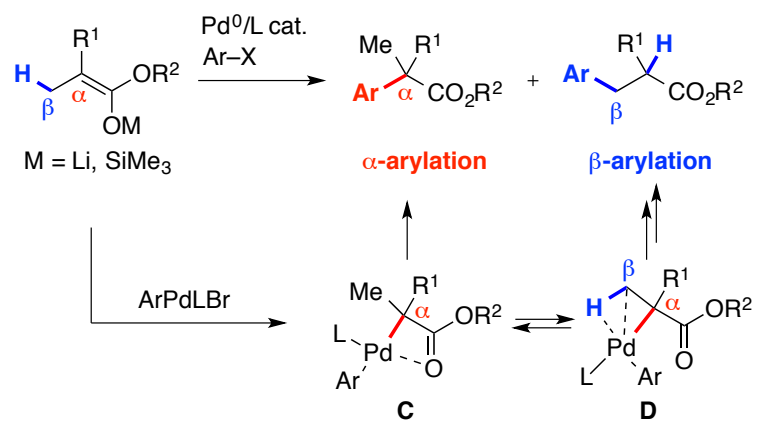

\section{RESULTS AND DISCUSSION}

Catalytic reactions with representative biarylphosphines. The effect of four representative biarylphosphine ligands on the selectivity of the arylation of the lithium enolate of tert-butylisobutyrate 1 with two different aryl bromides is shown in Table 1 . With $m$ fluorobromobenzene $\mathbf{2 a}$ as the electrophile, ligand $\mathbf{L}^{\mathbf{1}}$ (DavePhos) $)^{6}$ furnished an $\alpha / \beta(\mathbf{3 a} / \mathbf{4 a})$ ratio of $47: 53$, in line with previous results (entry 1 ). ${ }^{2 \mathrm{a}-\mathrm{b}} \mathrm{A}$ similar ratio was obtained with second generation imidazole-based ligand $\mathbf{L}^{2}$ (entry 2). ${ }^{2 c-d}$ Ligand $\mathbf{L}^{3},{ }^{7}$ which is isosteric to $\mathbf{L}^{1}$, significantly altered the $\alpha / \beta$ ratio in favor of $\alpha$ arylated product $\mathbf{3 a}$ (entry 3 ). CPhos $\mathbf{L}^{4}$, bearing two $\mathrm{NMe}_{2}$ groups on the non-phosphine-containing ring, ${ }^{8}$ had a dramatic effect on the selectivity, with 3a being exclusively obtained (entry 4). This is consistent with the fact that this ligand was developed to avoid Pd migration in Negishi-type cross-couplings. The same overall trend was observed with aryl bromide $\mathbf{2 b}$ bearing two strong electron-withdrawing $\mathrm{CF}_{3}$ groups at the meta positions (entries 5-8). Indeed, ligands $\mathbf{L}^{1}-\mathbf{L}^{2}$ bearing only one $\mathrm{NMe}_{2}$ group mainly gave $\beta$-arylated product $4 \mathbf{b}$ (entries 5-6), whereas ligand $\mathbf{L}^{4}$ gave $\mathbf{3 b}$ as the major product (entry 8), and ligand $\mathbf{L}^{3}$ was somewhat in between (entry 7). However, the impact of the ligand on the arylation selectivity was less pronounced for aryl bromide $\mathbf{2 b}$ compared to $\mathbf{2} \mathbf{a}$, in line with previous results. This is due to a higher degree of substrate- 
controlled selectivity for aryl bromide $\mathbf{2 b}$ containing two strongly electron-withdrawing $\mathrm{CF}_{3}$ groups. Hence, the nature and number of ortho substituents on the nonphosphine-containing ring of ligands $\mathbf{L}^{\mathbf{1}}-\mathbf{L}^{\mathbf{4}}$ have a marked effect on the arylation selectivity, thereby pointing to the influence of electronic and/or conformational factors within the Pd intermediates during the reaction. To further investigate these effects, ligands $\mathbf{L}^{\mathbf{1}}-\mathbf{L}^{\mathbf{4}}$ were chosen for the preparation and study of arylpalladium bromide and malonate complexes.

Table 1. Effect of Representative Biarylphosphine Ligands on the $\alpha / \beta$ Selectivity of the Arylation of Ester Enolates ${ }^{a}$

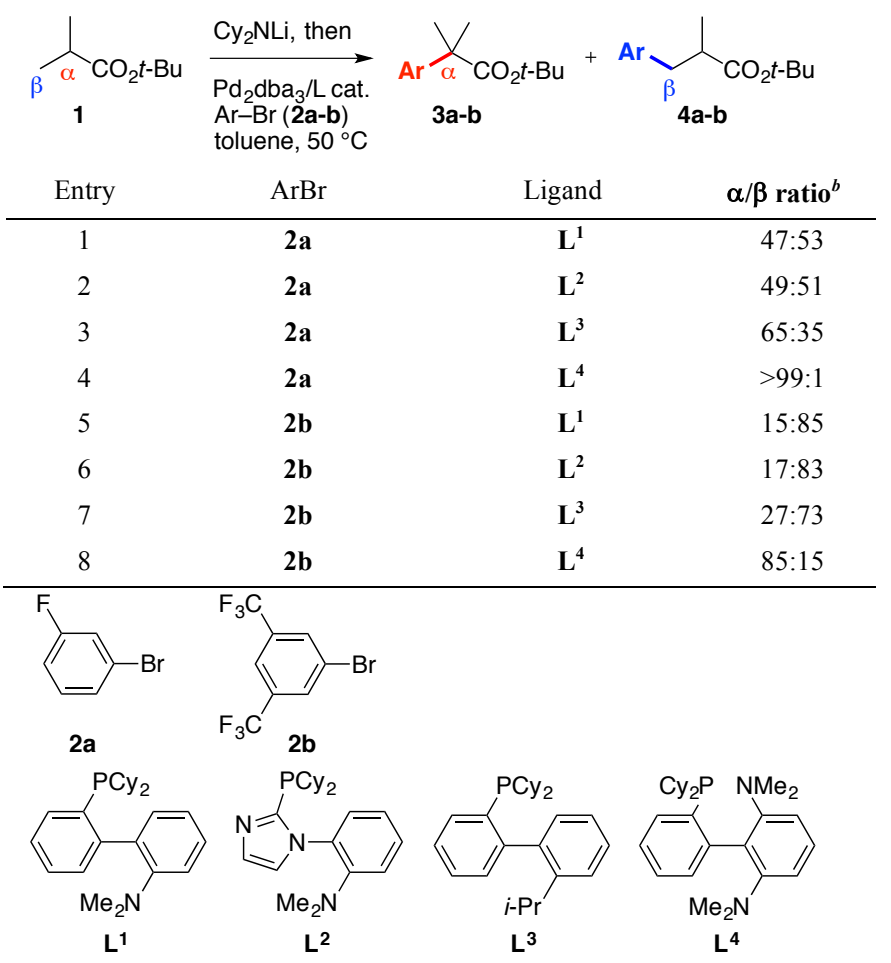

${ }^{a}$ Reaction conditions: 1 (1.6 equiv), $\mathrm{Cy}_{2} \mathrm{NLi}$ (1.7 equiv), aryl bromide ( 1 equiv), $\mathrm{Pd}_{2} \mathrm{dba}_{3}$ (5 mol\%), ligand (10 mol\%), toluene, $50{ }^{\circ} \mathrm{C} .{ }^{b}$ Determined by ${ }^{19} \mathrm{~F}$ NMR.

Synthesis and characterization of oxidative addition complexes containing ligands $\mathbf{L}^{\mathbf{1}}-\mathbf{L}^{\mathbf{4}}$. Palladium complexes $\mathbf{A}^{\mathbf{1}}-\mathbf{A}^{\mathbf{4}}$ were prepared in one step by addition of 2b to a 1:1 mixture of the appropriate ligand and (COD) $\mathrm{Pd}\left(\mathrm{CH}_{2} \mathrm{SiMe}_{3}\right)_{2}$ in $\mathrm{THF}$ at $20{ }^{\circ} \mathrm{C}$, and they were isolated as pure solids in reasonable yields (48-86\%). Aryl bromide 2b was chosen after initial investigations with $2 \mathbf{a}$ due to a higher stability of the corresponding bromide and malonate complexes (vide infra). Indeed, the strong electron-withdrawing $\mathrm{CF}_{3}$ substituents in $\mathbf{2 b}$ should stabilize the corresponding aryl-palladium complexes by strengthening the $\mathrm{C}_{\mathrm{Ar}}-\mathrm{Pd}$ bond. ${ }^{2 \mathrm{~b}, 9}$ Suitable monocrystals of $\mathbf{A}^{\mathbf{1}}-\mathbf{A}^{\mathbf{3}}$ were readily obtained from a $\mathrm{CDCl}_{3} /$ hexane mixture, and the corresponding X-ray structures are shown in Figure 1. In the solid state, complexes $\mathbf{A}^{\mathbf{1}}-\mathbf{A}^{\mathbf{3}}$ display a bromo-bridged dimeric structure $\left(\mathbf{A}_{\text {dim }} \mathbf{A}^{\mathbf{3}}{ }_{\text {dim }}\right)$, with $\mathbf{A}_{\text {dim }}{ }^{1}$ having a bent character between the two palladium units along the $\mathrm{Br}-\mathrm{Br}$ axis $\left(137.2^{\circ}\right)$, presumably to minimize steric repulsions between the respective $\mathbf{L}^{\mathbf{1}}$ ligands. In all structures the sum of the angles around the palladium center ranging between $359.6^{\circ}-361.7^{\circ}$ demonstrates planarity at the metal with only minor distortions. In contrast, the X-ray crystallographic analysis of complex $\mathbf{A}^{4}$ revealed a monomeric species featuring an interaction between the palladium center and the biphenyl ipso carbon $\left(\mathrm{C}_{16}\right)$. The presence of this type of $\mathrm{Pd}-\mathrm{C}_{\text {ipso }}$ bond in palladium(II)biarylphosphine oxidative addition complexes has been previously reported with $\mathrm{CPhos} \mathbf{L}^{4}$ as the ligand ${ }^{8 \mathrm{~b}}$ and in structurally related BrettPhos-type ligands bearing $i$-Pr instead of $\mathrm{NMe}_{2}$ groups. ${ }^{10}$ The $\mathrm{Pd}-\mathrm{C}_{\text {ipso }}$ bond length of 2.467(3) $\AA$ in $\mathbf{A}^{4}$ lies in the range of distances reported in these CPhos (2.478 $\AA$ ) and BrettPhos-based complexes (2.439-2.527 $\AA$ ). As expected, the $\mathrm{Pd}-\mathrm{C}_{\text {ipso }}$ interaction causes a pyramidalization at $\mathrm{C}_{16}$ and an elongation of the $\mathrm{C}_{16}-\mathrm{C}_{17}$ and $\mathrm{C}_{16}-\mathrm{C}_{24}$ aromatic bonds to 1.431(4) and $1.442(4) \AA$, respectively. In addition, the $\mathrm{C}_{24}-\mathrm{N}_{25}$ bond is significantly shorter $(1.383(4) \AA)$ than the other ortho $\mathrm{C}_{17}-\mathrm{N}_{18}$ bond (1.432(4) $\AA$ ) and $\mathrm{N}_{25}$ is less pyramidalized than $\mathrm{N}_{18}$ (sum of the bond angles at $\mathrm{N}_{25}$ and $\mathrm{N}_{18}: 355.0$ and $338.6^{\circ}$, respectively), thereby indicating a nonsymmetrical participation of these nitrogen atoms to the bonding interaction with $\mathrm{Pd}^{11}$ In contrast to $\mathbf{A}^{\mathbf{4}}$, complexes $\mathbf{A}_{\mathbf{d i m}^{\mathbf{1}}}-\mathbf{A}^{\mathbf{3}}{ }_{\text {dim }}$ do not show any real bonding interaction between $\mathrm{Pd}$ and the non-phosphine-containing ring of the ligand in the solid state. Indeed, the Pd atom shows no pyramidalization in $\mathbf{A}_{\mathbf{d i m}}^{\mathbf{1}}-\mathbf{A}^{\mathbf{3}} \mathbf{d i m}$, with its coordination sphere being completed by the $\mu$-bromo ligand, and the shortest distance between $\mathrm{Pd}$ and the nonphosphine-containing ring ranges from $3.06\left(\mathbf{A}_{\text {dim }}^{3}\right)$ to $3.42 \AA\left(\mathbf{A}^{\mathbf{1}}{ }_{\mathrm{dim}}\right)$ (Figure 1). In addition, the ortho $\mathrm{NMe}_{2}$ or $i$-Pr group in $\mathbf{A}_{\text {dim }}^{\mathbf{2}}-\mathbf{A}^{\mathbf{3}}{ }_{\text {dim }}$ is pointing away from the metal, whereas the $\mathrm{NMe}_{2}$ group is pointing toward $\mathrm{Pd}$ in $\mathbf{A}^{\mathbf{1}}{ }_{\text {dim. }}$. It should be also noted that imidazole-based ligand $\mathbf{L}^{2}$ does not exhibit coordination of Pd by the imidazole nitrogen atom, in contrast to a previous X-ray structure with an analogous ligand. ${ }^{12}$ 

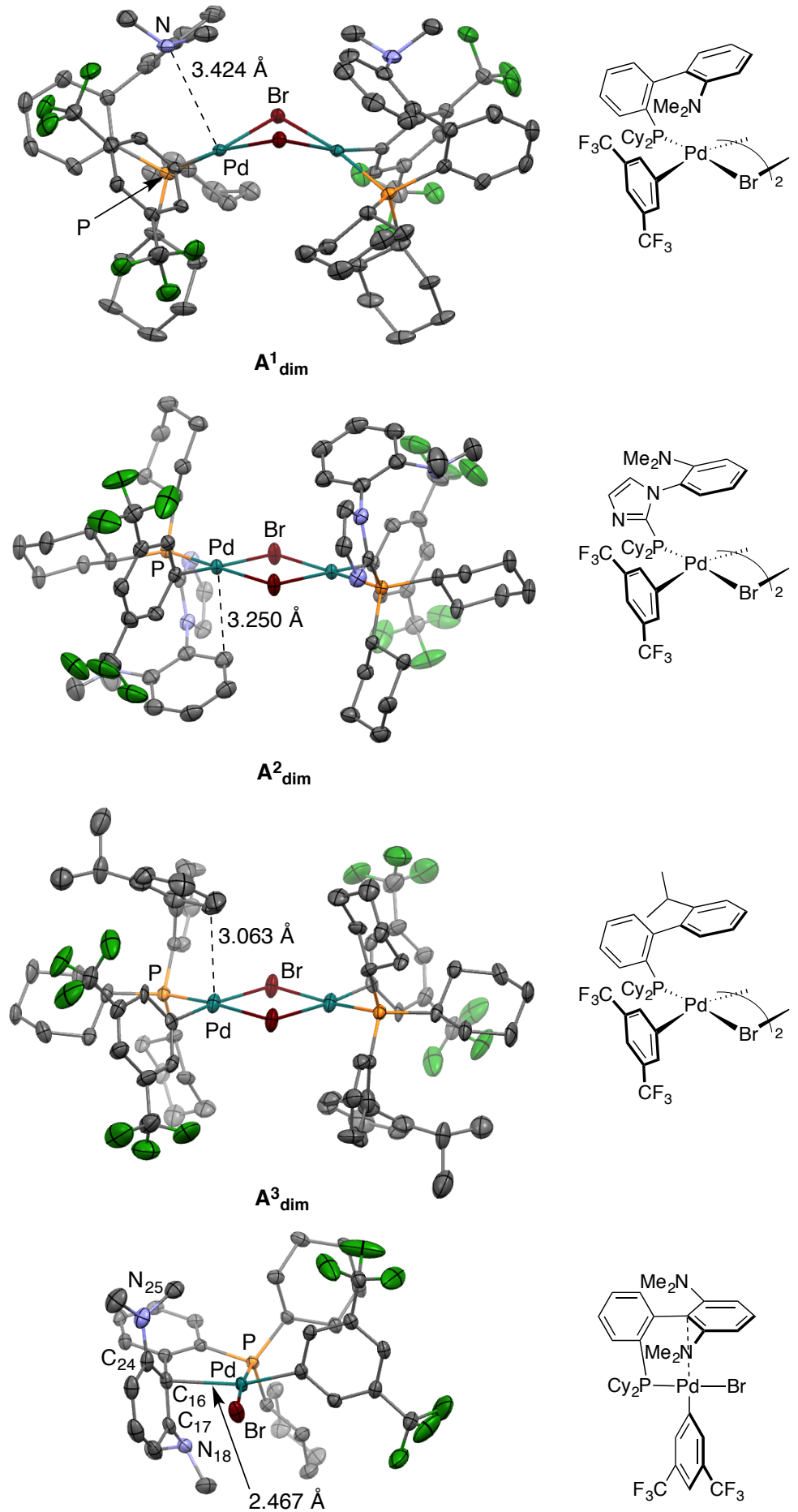

$A^{4}$

Figure 1. X-ray crystal structures of oxidative addition complexes $\mathbf{A}^{\mathbf{1}}-\mathbf{A}^{\mathbf{4}}$ showing selected distances (ellipsoids at $50 \%$ probability, $\mathrm{H}$ atoms omitted for clarity).

Thus, the above structures highlight a significant bonding behavior between ligands $\mathbf{L}^{1}-\mathbf{L}^{3}$ and $\mathbf{L}^{4}$. In solution in $\mathrm{CDCl}_{3}$ at $20{ }^{\circ} \mathrm{C}$, complex $\mathbf{A}^{\mathbf{1}}$ mainly occurs as the bromo-bridged dimer $\mathbf{A}^{\mathbf{1}}{ }_{\text {dim }}$, as indicated by the presence of a sharp singlet resonating at 29.8 ppm in ${ }^{31} \mathrm{P}\left\{{ }^{1} \mathrm{H}\right\}$
NMR (see the Supporting Information). However, in $\mathrm{C}_{6} \mathrm{D}_{6}$, i. e. in a solvent that has closer properties to the actual solvent employed in catalysis (toluene), the ${ }^{31} \mathrm{P}\left\{{ }^{1} \mathrm{H}\right\}$ NMR spectrum of $\mathbf{A}^{\mathbf{1}}$ shows a broad signal resonating at $54 \mathrm{ppm}$, characteristic of a monomeric species. This observation is in accordance with NMR studies by Buchwald, Barder and co-workers. ${ }^{3 \mathrm{c}}$ Similarly, ${ }^{31} \mathrm{P}\left\{{ }^{1} \mathrm{H}\right\}$ NMR analyses indicate that complexes $\mathbf{A}^{2}-\mathbf{A}^{3}$ occur as monomeric species in $\mathrm{C}_{6} \mathrm{D}_{6}$ and as mixtures of monomer and bromo-bridged dimer in $\mathrm{CDCl}_{3}$. In contrast, complex $\mathbf{A}^{4}$ occurs as a single monomeric species in $\mathrm{CDCl}_{3}$, in agreement with previous data. ${ }^{8 \mathrm{~b}}$ However, its ${ }^{31} \mathrm{P}\left\{{ }^{1} \mathrm{H}\right\}$ NMR spectrum in $\mathrm{C}_{6} \mathrm{D}_{6}$ shows two signals ascribed to two different monomeric species. ${ }^{3 \mathrm{c}}$ Unfortunately, we were unable to obtain additional information from NMR data due to the fluxional behavior of the above complexes, even by performing variable temperature experiments.

Synthesis and characterization of malonate complexes containing ligands $\mathbf{L}^{1}-\mathbf{L}^{4}$. On the basis of DFT calculations, we previously proposed that $\alpha$-arylated products $(\mathbf{3 a - b}$, Table 1$)$ arise from the reductive elimination of $\mathrm{O}$ bound Pd enolate $\mathbf{C}$ (Scheme 1). ${ }^{2 b}$ On the other hand, the equilibration of $\mathbf{C}$ to $\beta$-agostic complex $\mathbf{D}$ opens up the $\beta$-arylation pathway, which proceeds through $\beta$-hydride elimination, rotation, insertion and reductive elimination. ${ }^{2 b}$ Culkin and Hartwig showed that the stability of arylpalladium enolate-diphosphine complexes is inversely proportional to the substitution at the $\alpha$ carbon. ${ }^{13}$ In accordance with these results, we were unable to isolate $\mathrm{Pd}$ enolates from the reaction of the potassium enolate of 1 with oxidative addition complexes $\operatorname{ArPdLBr}(\mathrm{L}=$ biarylphosphine). As a consequence, we turned our attention to malonate complexes, as more stable surrogates of $\mathrm{Pd}$ enolates C-D. ${ }^{14}$ We initially attempted to prepare such a complex from the oxidative addition complex, obtained from DavePhos $\mathbf{L}^{1}$ and 1-bromo-2-fluorobenzene, that we previously reported. ${ }^{2 b}$ Unfortunately in this case, we were not able to isolate the malonate complex, and observed the formation of the $\alpha$-arylated product. Although it proved difficult to prepare malonate complexes that were sufficiently stable to be isolated and crystallized, we found that the presence of the two electron-withdrawing $\mathrm{CF}_{3}$ groups on the aryl ligand provided the required stability. Metathetical exchange between the potassium salt of dimethyl malonate (5a) and the bromide ligand in com- 

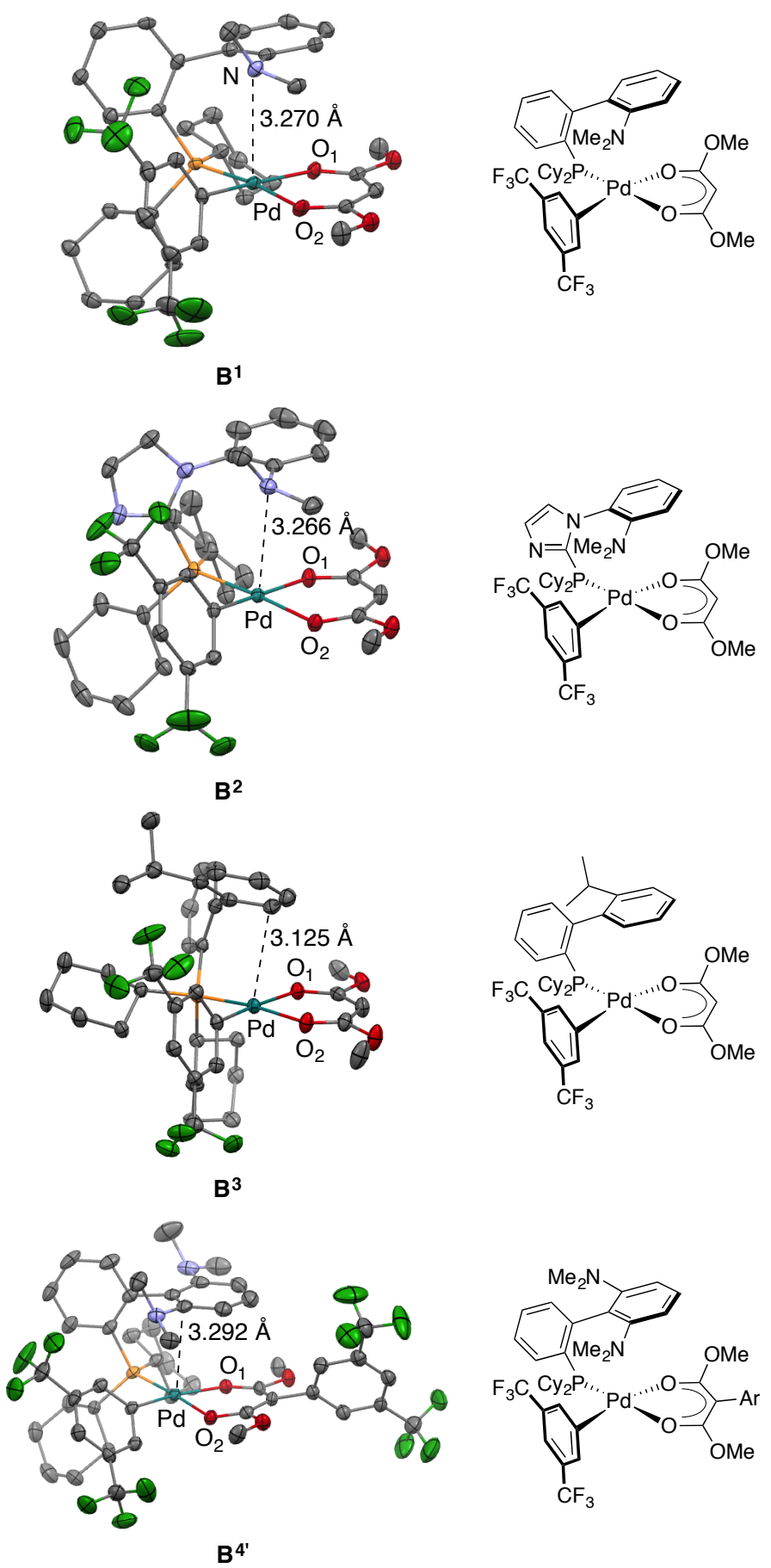

Figure 2. X-ray crystal structures of malonate complexes $\mathbf{B}^{\mathbf{1}}-\mathbf{B}^{\mathbf{3}}$ and $\mathbf{B}^{4}$ ' showing selected distances (ellipsoids at $50 \%$ probability, $\mathrm{H}$ atoms omitted for clarity).

plexes $\mathbf{A}^{\mathbf{1}}-\mathbf{A}^{\mathbf{3}}$ readily occurred in THF at $0{ }^{\circ} \mathrm{C}$ to generate the $\kappa^{2}-\mathrm{O}, \mathrm{O}^{\prime}$-bound palladium dimethyl malonate complexes $\mathbf{B}^{1}-\mathbf{B}^{\mathbf{3}}$ which could be fully characterized. The Xray crystal structures of $\mathbf{B}^{\mathbf{1}}-\mathbf{B}^{\mathbf{3}}$ are shown in Figure 2. No unusual angles at the palladium center were found in $\mathbf{B}^{\mathbf{1}}$ $\mathbf{B}^{3}$. As expected, the $\mathrm{Pd}-\mathrm{O}_{1}$ bonds trans to the aryl ligand are longer than the $\mathrm{Pd}-\mathrm{O}_{2}$ bonds trans to the phosphine ligand (2.107(3) $\AA$ vs. 2.091(1) $\AA$ for $\mathbf{B}^{\mathbf{1}} ; 2.115(1)$
$\AA$ vs. $2.094(1) \AA$ for $\mathbf{B}^{2} ; 2.115(2) \AA$ vs. $2.095(2) \AA$ for $\mathbf{B}^{\mathbf{3}}$ ). The spatial orientations of the biaryl moieties of the phosphine ligands observed in $\mathbf{A}_{\mathbf{d i m}^{\mathbf{1}}}^{\mathbf{A}} \mathbf{A}^{\mathbf{3}}{ }_{\mathrm{dim}}$ are preserved in $\mathbf{B}^{\mathbf{1}}$ and $\mathbf{B}^{\mathbf{3}}$, but a rotation of the nonphosphine-containing ring of the ligand is observed in $\mathbf{B}^{2}$, thus placing the nitrogen atom of the $\mathrm{NMe}_{2}$ moiety at the pseudo-apical position of the Pd center, similar to $\mathbf{B}^{\mathbf{1}}$. The shortest distances between this aromatic ring and $\mathbf{P d}$ in $\mathbf{B}^{\mathbf{1}}-\mathbf{B}^{\mathbf{3}}$ ranges from 3.12 to $3.27 \AA$, with no significant pyramidalization at the Pd center, and thus with no particular bonding character, similar to the corresponding oxidative addition complexes $\mathbf{A}_{\text {dim }}^{\mathbf{1}}-\mathbf{A}_{\text {dim }}^{\mathbf{3}}$.

Finally, malonate complex $\mathbf{B}^{4}$ was readily obtained from complex $\mathbf{A}^{4}$ under the same reaction conditions (Scheme 2). However, when $\mathbf{B}^{4}$ was left to crystallize at $5{ }^{\circ} \mathrm{C}$ in a $\mathrm{C}_{6} \mathrm{D}_{6}$ /hexane mixture, we were surprised to obtain the crystal structure of the parent complex $\mathbf{B}^{\mathbf{4}}$ 'bearing the arylated malonate. Complex $\mathbf{B}^{\mathbf{A}^{\prime}}$ displays the same $\kappa^{2}$-O,O'-coordination mode and overall structure as complexes $\mathbf{B}^{\mathbf{1}}-\mathbf{B}^{\mathbf{3}}$ (Figure 2, bottom right). It is probably formed by displacement of the malonate ligand in $\mathbf{B}^{4}$ by the in situ-formed arylated malonate anion $\mathbf{5 b}$, arising from reductive elimination of the putative $\mathrm{C}$-enolate $\mathbf{B}^{4 "}$. In addition, $\mathbf{B}^{4}$ could be obtained directly from $\mathbf{A}^{4}$ and malonate anion $\mathbf{5 b}$ in a separate experiment. DFT modeling of the isodesmic reaction between $\mathbf{B}^{4}$ and $\mathbf{B}^{\mathbf{4}^{\prime}}$ showed that the formation of $\mathbf{B}^{\mathbf{4}}$ is thermodynamically favored by $4.6 \mathrm{kcal} \mathrm{mol}^{-1}$, which accounts for the isolation of $\mathbf{B}^{4}$ ' rather than $\mathbf{B}^{4}$.

Discussion. The above results show that CPhos $\mathbf{L}^{4}$ behaves differently from the other studied ligands in both oxidative addition, where it adopts a bidentate binding mode, and malonate, where it seems to favor reductive elimination, complexes. This behavior can be inferred to the reduced conformational freedom at the biaryl bond of $\mathbf{L}^{4}$ compared to $\mathbf{L}^{\mathbf{1}}-\mathbf{L}^{3}$, which should lower the energy barrier of $\mathrm{C}-\mathrm{C}$ reductive elimination by virtue of steric decompression. ${ }^{13-14}$ This property allows to explain the high $\alpha$ selectivity selectivity in the arylation of $t$-butyl isobutyrate 1 with this ligand (Table 1). Indeed, the two selectivity-determining steps were shown to be the $\alpha$-reductive elimination and the olefin insertion with DavePhos $\mathbf{L}^{1}$ as the ligand. ${ }^{2 b}$ With a more rigid ligand such as $\mathrm{CPhos} \mathbf{L}^{4}$, $\alpha$-reductive elimination should become energetically more favorable and Pd migration less favorable, thereby favoring the $\alpha$-arylated product (3a-b). Nevertheless, other factors must be involved, as shown with the selectivity differences observed among ligands $\mathbf{L}^{\mathbf{1}}-\mathbf{L}^{\mathbf{3}}$, which form structurally similar oxidative addition and malonate complexes. In particular, the hemilabile character of $\mathrm{NMe}_{2}$-containing ligands $\mathbf{L}^{\mathbf{1}}-\mathbf{L}^{\mathbf{2}}$ seems to be an important parameter in 
Scheme 2. Formation of Malonate Complex $\mathrm{B}^{4}{ }^{a}$

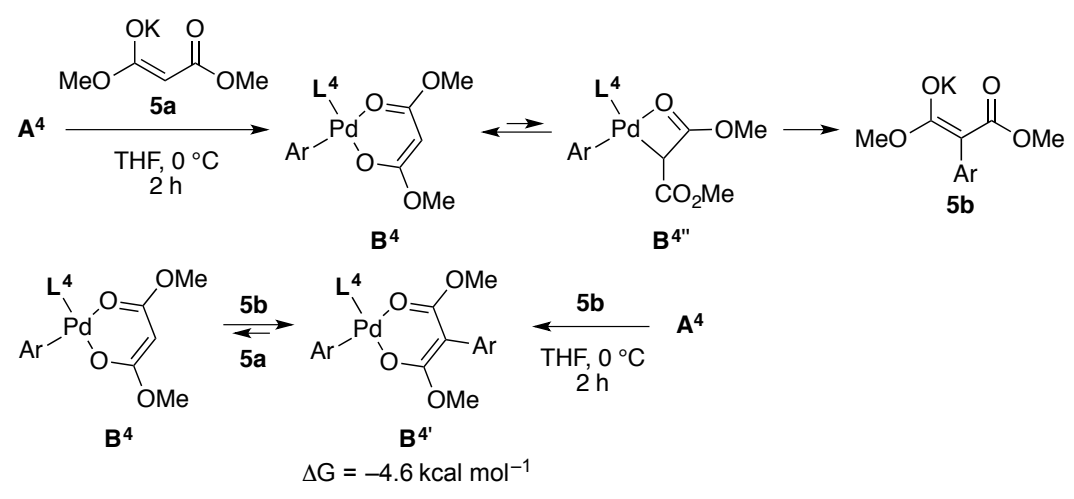

${ }^{a} \mathrm{Ar}=m-\left(\mathrm{CF}_{3}\right)_{2} \mathrm{Ph}$

comparison with $\mathbf{L}^{3}$, which is isosteric but lacks the nitrogen coordinating group. The current study does not allow to decipher this more subtle effect, and further investigations with more dynamic reaction models ${ }^{3}$ will be conducted in the future to address this challenging issue.

\section{CONCLUSION}

This study represents a first step toward the understanding of the origins of the ligand-induced selectivity in the normal $(\alpha) v s$. migrative $(\beta)$ arylation of ester enolates. The solid-state structures of two types of arylpalladium complexes, i. e. oxidative addition and malonate, were solved with four representative biarylphosphine ligands. These data highlight the influence of the ligand rigidity, with $\mathrm{CPhos}\left(\mathbf{L}^{\mathbf{4}}\right)$ showing higher bidentate character and rigidity compared to ligands $\mathbf{L}^{1}-\mathbf{L}^{3}$ bearing only one ortho substituent on the non-phosphine containing benzene ring. This rigidity (or conversely, flexibility) is likely a key factor in the control of the arylation selectivity.

\section{EXPERIMENTAL SECTION}

General Considerations. Reactions were performed under an atmosphere of argon with rigorous exclusion of moisture from reagents and glassware using standard techniques. Commercially available reagents were used without further purification unless otherwise stated. All bases, phosphines and palladium sources were stored in a glove box. Anhydrous solvents were obtained by distillation over calcium hydride ( $n$-hexane) or sodium / benzophenone (THF, toluene). IR spectra were recorded on an FTIR spectrometer and data are reported in reciprocal centimeters $\left(\mathrm{cm}^{-1}\right)$. NMR spectra $\left({ }^{1} \mathrm{H},{ }^{13} \mathrm{C},{ }^{19} \mathrm{~F}\right.$ and $\left.{ }^{31} \mathrm{P}\right)$ were recorded on a 300 , 400 or 500 spectrometer in $\mathrm{CDCl}_{3}$ (residual peaks ${ }^{1} \mathrm{H} \delta$ $7.26,{ }^{13} \mathrm{C} \delta 77.16$ ) or $\mathrm{C}_{6} \mathrm{D}_{6}$ (residual peaks ${ }^{1} \mathrm{H} \delta 7.16,{ }^{13} \mathrm{C} \delta$ 128.06). Chemical shifts are reported relative to the chemical shift of the residual solvent for ${ }^{1} \mathrm{H}$ and ${ }^{13} \mathrm{C}$ NMR. ${ }^{19} \mathrm{~F}$ NMR and ${ }^{31} \mathrm{P}$ NMR spectra are calibrated with an external reference $\left(\mathrm{CFCl}_{3}, \delta 0.0\right.$, and $\mathrm{H}_{3} \mathrm{PO}_{4}, \delta 0.0$, respectively) and recorded with complete proton decoupling. Data are reported as follows: chemical shift in parts per million ( $\mathrm{ppm})$, multiplicity $(\mathrm{s}=$ singlet, $\mathrm{d}=$ doublet, $\mathrm{t}=$ triplet, $\mathrm{q}=$ quartet, $\mathrm{m}=$ multiplet, and $\mathrm{br}=$ broad), integration value, coupling constant in $\mathrm{Hz}$ if applicable.

General Procedure A for the Synthesis of Oxidative Addition Complexes. A Schlenk tube was charged with $\left[\mathrm{Pd}(\mathrm{COD})\left(\mathrm{CH}_{2} \mathrm{SiMe}_{3}\right)_{2}\right]^{15} \quad(200 \mathrm{mg}, \quad 0.52$ mmol, 1.0 equiv) and phosphine ligand ( $0.52 \mathrm{mmol}, 1.0$ equiv), and the solids were dissolved in THF $(20 \mathrm{~mL})$. 1-Bromo-3,5bis(trifluoromethyl)benzene $(0.44 \mathrm{~mL}, 754.0$ $\mathrm{mg}, 2.58 \mathrm{mmol}$, 5.0 equiv) was then added to the solution and the reaction mixture was stirred for $16 \mathrm{~h}$ at $\mathrm{rt}$. All the volatiles were then removed under vacuum and $n$-hexanes were added. After filtration by cannula transfer under a positive pressure of argon, the solid was dried under vacuum. Crystallization was achieved using NMR Young tubes with $\mathrm{CDCl}_{3} / n$-hexanes or $\mathrm{C}_{6} \mathrm{D}_{6} / n$-hexanes solvent mixtures. Complex $\mathbf{A}^{\mathbf{1}}$. Complex $\mathbf{A}^{\mathbf{1}}$ was synthesized according to general procedure A using DavePhos $\mathbf{L}^{1}(204 \mathrm{mg})$ as the ligand. The title complex was obtained as a grey solid in $86 \%$ yield, and was crystallized in $\mathrm{CDCl}_{3} / n$-hexanes. ${ }^{1} \mathrm{H}$ NMR (400 MHz, $\left.\mathrm{CDCl}_{3}, 293 \mathrm{~K}\right) \delta 0.95-1.15(\mathrm{~m}, 4 \mathrm{H}), 1.42-$ $1.62(\mathrm{~m}, 6 \mathrm{H}), 1.64-1.74(\mathrm{~m}, 3 \mathrm{H}), 1.77-1.83(\mathrm{~m}, 2 \mathrm{H}), 1.88$ $1.97(\mathrm{~m}, 3 \mathrm{H}), 1.99-2.09(\mathrm{~m}, 1 \mathrm{H}), 2.26-2.35(\mathrm{~m}, 1 \mathrm{H}), 2.59-$ $2.72(\mathrm{~m}, 2 \mathrm{H}), 3.01(\mathrm{~s}, 6 \mathrm{H}), 6.94-7.03(\mathrm{~m}, 2 \mathrm{H}), 7.07-7.11$ $(\mathrm{m}, 1 \mathrm{H}), 7.13-7.17(\mathrm{~m}, 1 \mathrm{H}), 7.31-7.44(\mathrm{~m}, 4 \mathrm{H}), 7.56-7.62$ (m, 1H), 7.64-7.71 (m, 2H). ${ }^{13} \mathrm{C}$ NMR $\left(100.6 \mathrm{MHz}, \mathrm{CDCl}_{3}\right.$, $293 \mathrm{~K}) \delta 25.4\left(\mathrm{CH}_{2}\right), 26.0\left(\mathrm{CH}_{2}\right), 26.4\left(\mathrm{CH}_{2}\right), 26.9-27.5(\mathrm{~m}$, $\left.\mathrm{CH}_{2}\right), 28.9\left(\mathrm{~d}, J_{\mathrm{CP}}=3.6 \mathrm{~Hz}, \mathrm{CH}_{2}\right), 30.6\left(\mathrm{CH}_{2}\right), 35.2\left(\mathrm{~d},{ }^{1} J_{\mathrm{CP}}\right.$ $=23.9 \mathrm{~Hz}, \mathrm{CH}), 36.3\left(\mathrm{~d},{ }^{1} J_{\mathrm{CP}}=29.5 \mathrm{~Hz}, \mathrm{CH}\right), 44.3\left(2 \mathrm{CH}_{3}\right)$, $117.5(\mathrm{CH}), 118.3(\mathrm{CH}), 120.2(\mathrm{CH}), 123.7\left(\mathrm{q},{ }^{1} J_{\mathrm{CF}}=272.8\right.$ $\left.\mathrm{Hz}, 2 \mathrm{C}_{\mathrm{q}}\right), 125.9(\mathrm{CH}), 127.1\left(\mathrm{~d}, J_{\mathrm{CP}}=5.7 \mathrm{~Hz}, \mathrm{CH}\right), 128.4$ $\left(\mathrm{d}, J_{\mathrm{CP}}=35.0 \mathrm{~Hz}, \mathrm{C}_{\mathrm{q}}\right), 128.6\left(\mathrm{q},{ }^{2} J_{\mathrm{CF}}=31.7 \mathrm{~Hz}, 2 \mathrm{C}_{\mathrm{q}}\right), 129.5$ $(\mathrm{CH}), 131.7(\mathrm{CH}), 132.8(\mathrm{CH}), 135.2(\mathrm{CH}), 136.0(\mathrm{CH})$, $138.4(\mathrm{CH}), 141.7\left(\mathrm{C}_{\mathrm{q}}\right), 145.5\left(\mathrm{C}_{\mathrm{q}}\right), 151.1\left(\mathrm{~d}, J_{\mathrm{CP}}=17.7 \mathrm{~Hz}\right.$, $\left.\mathrm{C}_{\mathrm{q}}\right), 156.3\left(\mathrm{C}_{\mathrm{q}}\right) .{ }^{31} \mathrm{P}$ NMR $\left(121.5 \mathrm{MHz}, \mathrm{C}_{6} \mathrm{D}_{6}, 293 \mathrm{~K}\right) \delta$ 54.0. ${ }^{19} \mathrm{~F}$ NMR (282 MHz, $\left.\mathrm{C}_{6} \mathrm{D}_{6}, 293 \mathrm{~K}\right) \delta-61.7$. IR (neat) $v$ 2931, 2855, 1338, 1270, 1120. HRMS (ESI) $\mathrm{m} / z$ Calcd for $\mathrm{C}_{34} \mathrm{H}_{39} \mathrm{~F}_{6} \mathrm{NPPd}\left([\mathrm{M}-\mathrm{Br}]^{+}\right)$: 712.1767; found: 712.1776 .

Complex $\mathbf{A}^{2}$. Complex $\mathbf{A}^{\mathbf{2}}$ was synthesized according to general procedure A using 2-(2-(dicyclohexylphosphino)$1 H$-imidazol-1-yl)- $N, N$-dimethylaniline $\mathbf{L}^{2}(199 \mathrm{mg}$ ) as the ligand. After evaporation of THF, $n$-hexanes were added and the reaction mixture was filtered. After evaporation of the filtrate, the title complex was obtained as a yellow solid in $46 \%$ yield, and was crystallized in $\mathrm{CDCl}_{3} / n$-hexanes. ${ }^{1} \mathrm{H}$ NMR $\left(400 \mathrm{MHz}, \mathrm{C}_{6} \mathrm{D}_{6}, 293 \mathrm{~K}\right) \delta 0.75-0.96(\mathrm{~m}, 2 \mathrm{H}), 1.06-$ $1.16(\mathrm{~m}, 4 \mathrm{H}), 1.20-1.30(\mathrm{~m}, 1 \mathrm{H}), 1.46-1.75(\mathrm{~m}, 8 \mathrm{H}), 1.79$ $2.13(\mathrm{~m}, 4 \mathrm{H}), 2.16-2.36(\mathrm{~m}, 3 \mathrm{H}), 2.27$ (br s, 6H), 6.49 (br s, $1 \mathrm{H}), 6.83-6.91(\mathrm{~m}, 1 \mathrm{H}), 6.93-7.05(\mathrm{~m}, 2 \mathrm{H}), 7.14-7.23(\mathrm{~m}$, $3 \mathrm{H}), 7.48(\mathrm{~s}, 1 \mathrm{H}), 7.72-7.93$ (br s, $1 \mathrm{H}) .{ }^{13} \mathrm{C}$ NMR $(100.6$ $\left.\mathrm{MHz}, \mathrm{C}_{6} \mathrm{D}_{6}, 293 \mathrm{~K}\right) \delta 26.4\left(4 \mathrm{CH}_{2}\right), 27.6\left(2 \mathrm{CH}_{2}\right), 27.8$ $\left(4 \mathrm{CH}_{2}\right), 27.9\left(2 \mathrm{CH}_{2}\right), 30.6(\mathrm{br}), 31.7(\mathrm{br}), 38.1(\mathrm{br}), 43.9$ $\left(2 \mathrm{CH}_{3}\right), 117.3(\mathrm{CH}), 120.3(\mathrm{CH}), 122.5(\mathrm{CH}), 124.6\left(\mathrm{q},{ }^{1} J_{\mathrm{CF}}\right.$ 
$\left.=273 \mathrm{~Hz}, 2 \mathrm{C}_{\mathrm{q}}\right), 126.6(\mathrm{CH}), 128.4(\mathrm{CH}), 128.5\left(\mathrm{q},{ }^{2} J_{\mathrm{CF}}=\right.$ $\left.31.8 \mathrm{~Hz}, 2 \mathrm{C}_{\mathrm{q}}\right), 128.7\left(\mathrm{C}_{\mathrm{q}}\right), 130.3\left(\mathrm{C}_{\mathrm{q}}\right), 130.9(\mathrm{CH}), 131.0$ $(\mathrm{CH}), 131.1(\mathrm{CH}), 137.0(\mathrm{CH}), 150.0\left(\mathrm{C}_{\mathrm{q}}\right), 152.7\left(\mathrm{C}_{\mathrm{q}}\right) .{ }^{31} \mathrm{P}$ NMR $\left(121 \mathrm{MHz}, \mathrm{C}_{6} \mathrm{D}_{6}, 293 \mathrm{~K}\right) \delta 33.8 .{ }^{19} \mathrm{~F}$ NMR $(282$ $\left.\mathrm{MHz}, \mathrm{C}_{6} \mathrm{D}_{6}, 293 \mathrm{~K}\right) \delta-61.7$. IR (neat) $v 2937,2856,1340$, 1272, 1121. HRMS (ESI) $\mathrm{m} / z$ Calcd for $\mathrm{C}_{31} \mathrm{H}_{37} \mathrm{BrF}_{6} \mathrm{~N}_{3} \mathrm{PPdNa} \quad\left([\mathrm{M}+\mathrm{Na}]^{+}\right): \quad 804.0745 ;$ found: 804.0708.

Complex $\mathbf{A}^{\mathbf{3}}$. Complex $\mathbf{A}^{\mathbf{3}}$ was synthesized according to general procedure A using dicyclohexyl-(2'isopropylbiphenyl-2-yl)phosphine $\mathbf{L}^{\mathbf{3}}$ (204 $\mathrm{mg}$ ) as the ligand. The title complex was obtained as a yellow solid in $48 \%$ yield, and was crystallized in $\mathrm{CDCl}_{3} / n$-hexanes. ${ }^{1} \mathrm{H}$ NMR $\left(400 \mathrm{MHz}, \mathrm{C}_{6} \mathrm{D}_{6}, 323 \mathrm{~K}\right) \delta$ 0.93-1.07 (m, 6H), 1.15$1.33(\mathrm{~m}, 6 \mathrm{H}), 1.37-1.75(\mathrm{~m}, 11 \mathrm{H}), 1.78-2.09(\mathrm{~m}, 3 \mathrm{H}), 2.16-$ $2.50(\mathrm{~m}, 2 \mathrm{H}), 2.56-2.76(\mathrm{~m}, 1 \mathrm{H}), 6.87-7.05(\mathrm{~m}, 3 \mathrm{H})$, , 7.06$7.14(\mathrm{~m}, 1 \mathrm{H}), 7.17-7.38(\mathrm{~m}, 4 \mathrm{H}), 7.44(\mathrm{~s}, 1 \mathrm{H}), 7.67-7.86$ $(\mathrm{m}, 2 \mathrm{H}) .{ }^{13} \mathrm{C}$ NMR $\left(100.6 \mathrm{MHz}, \mathrm{C}_{6} \mathrm{D}_{6}, 293 \mathrm{~K}\right) \delta 23.2$ $\left(\mathrm{CH}_{3}\right), 23.4\left(\mathrm{CH}_{3}\right), 25.8\left(\mathrm{br}, \mathrm{CH}_{2}\right), 26.1-26.4\left(\mathrm{br}, \mathrm{CH}_{2}\right), 26.4$ $(\mathrm{CH}), 27.1-27.9$ (br, $\left.\mathrm{CH}_{2}\right), 30.2-30.6\left(\mathrm{br}, \mathrm{CH}_{2}\right), 30.4\left(\mathrm{~d},{ }^{1} J_{\mathrm{CP}}\right.$ $=4.5 \mathrm{~Hz}, \mathrm{CH}), 31.8$ (br s, $\left.\mathrm{CH}_{2}\right), 32.7-33.4\left(\mathrm{br}, \mathrm{CH}_{2}\right), 36.8-$ 38.9 (br, CH), 117.2 (br, CH), 124.5 (q, ${ }^{1} J_{\mathrm{CF}}=272.3 \mathrm{~Hz}$, $\left.2 \mathrm{C}_{\mathrm{q}}\right), 125.8(\mathrm{CH}), 126.5(\mathrm{CH}), 126.7(\mathrm{br}, \mathrm{CH}), 128.3(\mathrm{CH})$, $128.5\left(\mathrm{q},{ }^{2} J_{\mathrm{CF}}=33.4 \mathrm{~Hz}, 2 \mathrm{C}_{\mathrm{q}}\right), 129.2(\mathrm{CH}), 129.4\left(\mathrm{~d}, J_{\mathrm{CP}}=\right.$ $6.4 \mathrm{~Hz}, \mathrm{CH}), 130.7\left(\mathrm{~d}, J_{\mathrm{CP}}=10.9 \mathrm{~Hz}, \mathrm{CH}\right), 133.8(\mathrm{CH})$, 134.4-135.1 (CH), $137.0\left(\mathrm{C}_{\mathrm{q}}\right), 137.1(\mathrm{CH}), 139.9\left(\mathrm{C}_{\mathrm{q}}\right)$, $144.4\left(\mathrm{C}_{\mathrm{q}}\right), 147.0\left(\mathrm{C}_{\mathrm{q}}\right), 153.0\left(\mathrm{C}_{\mathrm{q}}\right) .{ }^{31} \mathrm{P}$ NMR $(202 \mathrm{MHz}$, $\left.\mathrm{C}_{6} \mathrm{D}_{6}, 293 \mathrm{~K}\right) \delta 44.0 .{ }^{19} \mathrm{~F}$ NMR $\left(376 \mathrm{MHz}, \mathrm{C}_{6} \mathrm{D}_{6}, 293 \mathrm{~K}\right) \delta-$ 61.8. IR (neat) $v$ 2934, 2857, 1340, 1273, 1123. HRMS (ESI) $\mathrm{m} / z$ Calcd for $\mathrm{C}_{35} \mathrm{H}_{40} \mathrm{~F}_{6} \mathrm{PPd}\left([\mathrm{M}-\mathrm{Br}]^{+}\right)$: 711.1814; found: 711.1798 .

Complex $\mathbf{A}^{4}$. Complex $\mathbf{A}^{4}$ was synthesized according to procedure A using CPhos $\mathbf{L}^{4}(227 \mathrm{mg})$ as the ligand. The title complex was obtained as a yellow solid in $70 \%$ yield, and was crystallized in $\mathrm{C}_{6} \mathrm{D}_{6} / n$-hexanes. ${ }^{1} \mathrm{H}$ NMR (400 $\left.\mathrm{MHz}, \mathrm{CDCl}_{3}, 293 \mathrm{~K}\right) \delta 0.91-1.03(\mathrm{~m}, 2 \mathrm{H}), 1.07-1.31(\mathrm{~m}$, $6 \mathrm{H}), 1.35-1.47(\mathrm{~m}, 2 \mathrm{H}), 1.53-1.63(\mathrm{~m}, 2 \mathrm{H}), 1.63-1.80(\mathrm{~m}$, $6 \mathrm{H}), 2.00-2.09(\mathrm{~m}, 2 \mathrm{H}), 2.13-2.26(\mathrm{~m}, 2 \mathrm{H}), 2.62(\mathrm{~s}, 12 \mathrm{H})$, 6.86-6.92 (m, 2H), 7.08-7.13 (m, 1H), 7.31-7.37 (m, 2H), 7.43-7.49 (m, 1H), 7.59-7.65 (m, 3H), 7.66-7.71 (m, 1H). ${ }^{13} \mathrm{C}$ NMR $\left(100.6 \mathrm{MHz}, \mathrm{CDCl}_{3}, 293 \mathrm{~K}\right) \delta 25.9\left(2 \mathrm{CH}_{2}\right), 27.5$ $\left(\mathrm{d}, J_{\mathrm{CP}}=10.9 \mathrm{~Hz}, 2 \mathrm{CH}_{2}\right), 27.6\left(\mathrm{~d}, J_{\mathrm{CP}}=11.7 \mathrm{~Hz}, 2 \mathrm{CH}_{2}\right)$, $29.4\left(2 \mathrm{CH}_{2}\right), 30.2\left(2 \mathrm{CH}_{2}\right), 36.9\left(\mathrm{~d},{ }^{1} J_{\mathrm{CP}}=24.3 \mathrm{~Hz}, 2 \mathrm{CH}\right)$, $45.1\left(4 \mathrm{CH}_{3}\right), 112.5\left(\mathrm{C}_{\mathrm{q}}\right), 114.9(2 \mathrm{CH}), 117.3(\mathrm{CH}), 123.7$ $\left(\mathrm{q},{ }^{1} J_{\mathrm{CF}}=272.1 \mathrm{~Hz}, 2 \mathrm{C}_{\mathrm{q}}\right), 126.1\left(\mathrm{~d}, J_{\mathrm{CP}}=5.5 \mathrm{~Hz}, \mathrm{CH}\right)$, $127.8\left(\mathrm{~d}, J_{\mathrm{CP}}=25.0 \mathrm{~Hz}, \mathrm{C}_{\mathrm{q}}\right), 128.6\left(\mathrm{q},{ }^{2} J_{\mathrm{CF}}=31.8 \mathrm{~Hz}, 2 \mathrm{C}_{\mathrm{q}}\right)$, $131.3(\mathrm{CH}), 133.5\left(\mathrm{C}_{\mathrm{q}}\right), 133.8\left(\mathrm{~d}, J_{\mathrm{CP}}=12.3 \mathrm{~Hz}, \mathrm{CH}\right)$, $134.1(\mathrm{CH}), 135.6(\mathrm{CH}), 136.4(2 \mathrm{CH}), 140.8\left(\mathrm{C}_{\mathrm{q}}\right), 146.9(\mathrm{~d}$, $\left.J_{\mathrm{CP}}=18.6 \mathrm{~Hz}, \mathrm{C}_{\mathrm{q}}\right), 157.5\left(\mathrm{C}_{\mathrm{q}}\right) .{ }^{31} \mathrm{P} \mathrm{NMR}\left(162 \mathrm{MHz}, \mathrm{CDCl}_{3}\right.$, $293 \mathrm{~K}) \delta 33.1 .{ }^{19} \mathrm{~F}$ NMR $\left(376 \mathrm{MHz}, \mathrm{CDCl}_{3}, 293 \mathrm{~K}\right) \delta-$ 62.4. IR (neat) $v 2933,2855,1339,1272,1123$. HRMS (ESI) $\mathrm{m} / z$ Calcd for $\mathrm{C}_{36} \mathrm{H}_{44} \mathrm{~F}_{6} \mathrm{~N}_{2} \mathrm{PPd}\left([\mathrm{M}-\mathrm{Br}]^{+}\right)$: 755.2189 ; found 755.2169.

Synthesis of Potassium Dimethyl Malonate (5a). Potassium dimethyl malonate was formed by the addition of 1 equiv of dimethyl malonate to a suspension of 1 equiv of $\mathrm{KH}$ in THF. The reaction mixture was stirred until no more degassing of $\mathrm{H}_{2}$ was observed. Volatiles were removed from the resulting solution. The resulting solid was washed with $n$-hexanes and stored in the glovebox at $-5^{\circ} \mathrm{C}$.

General Procedure B for the Synthesis of Malonate Complexes. A Schlenk flask was charged with potassium dimethyl malonate 5a (3.0 equiv) and THF and cooled to 0 ${ }^{\circ} \mathrm{C}$. The oxidative addition complex (1.0 equiv) in THF was then added at $0{ }^{\circ} \mathrm{C}$. The reaction mixture was stirred for $2 \mathrm{~h}$ at $0{ }^{\circ} \mathrm{C}$. After removing the volatiles under vacuum, toluene was added. The solution was filtered by cannula transfer under a positive pressure of argon. The resulting solution was concentrated, and precipitation was attempted by the addition of $n$-hexanes. When the product did not precipitate, it was directly crystallized in NMR Young tubes with $\mathrm{CDCl}_{3} / n$-hexanes or $\mathrm{C}_{6} \mathrm{D}_{6} / n$-hexanes solvent mixtures.

Complex $\mathbf{B}^{1}$. Complex $\mathbf{B}^{1}$ was synthesized according to procedure $\mathbf{B}$ from $\mathbf{A}^{\mathbf{1}}$ as the oxidative addition complex. Crystallization was performed in $\mathrm{C}_{6} \mathrm{D}_{6} / n$-hexanes. ${ }^{1} \mathrm{H}$ NMR $\left(500 \mathrm{MHz}, \mathrm{C}_{6} \mathrm{D}_{6}, 293 \mathrm{~K}\right) \delta$ 0.63-0.72 $(\mathrm{m}, 1 \mathrm{H}), 0.85-1.03$ $(\mathrm{m}, 4 \mathrm{H}), 1.08-1.19(\mathrm{~m}, 1 \mathrm{H}), 1.22-1.61(\mathrm{~m}, 12 \mathrm{H}), 1.70-1.77$ $(\mathrm{m}, 1 \mathrm{H}), 1.80-1.93(\mathrm{~m}, 2 \mathrm{H}), 2.10-2.18(\mathrm{~m}, 1 \mathrm{H}), 2.53(\mathrm{~s}$, $6 \mathrm{H}), 3.17(\mathrm{~s}, 3 \mathrm{H}), 3.23(\mathrm{~s}, 3 \mathrm{H}), 4.91(\mathrm{~s}, 1 \mathrm{H}), 6.85-6.89(\mathrm{~m}$, $1 \mathrm{H}), 6.97-7.04(\mathrm{~m}, 2 \mathrm{H}), 7.06-7.11(\mathrm{~m}, 2 \mathrm{H}), 7.12-7.19(\mathrm{~m}$, $3 \mathrm{H}), 7.65(\mathrm{~s}, 1 \mathrm{H}), 7.92$ (s, 2H). ${ }^{13} \mathrm{C}$ NMR $\left(126 \mathrm{MHz}, \mathrm{C}_{6} \mathrm{D}_{6}\right.$, $293 \mathrm{~K}) \delta 26.6\left(\mathrm{~d}, J_{\mathrm{CP}}=1.8 \mathrm{~Hz}, 2 \mathrm{CH}_{2}\right), 27.4\left(\mathrm{~d}, J_{\mathrm{CP}}=9.0\right.$ $\left.\mathrm{Hz}, \mathrm{CH}_{2}\right), 27.7\left(\mathrm{~d}, J_{\mathrm{CP}}=7.4 \mathrm{~Hz}, \mathrm{CH}_{2}\right), 28.1\left(\mathrm{~d}, J_{\mathrm{CP}}=13.9\right.$ $\left.\mathrm{Hz}, \mathrm{CH}_{2}\right), 28.6\left(\mathrm{~d}, J_{\mathrm{CP}}=16.4 \mathrm{~Hz}, \mathrm{CH}_{2}\right), 30.1\left(2 \mathrm{CH}_{2}\right), 31.5$ $\left(\mathrm{d}, J_{\mathrm{CP}}=5.9 \mathrm{~Hz}, \mathrm{CH}_{2}\right), 34.0\left(\mathrm{CH}_{2}\right), 34.7\left(\mathrm{~d},{ }^{1} J_{\mathrm{CP}}=20.3 \mathrm{~Hz}\right.$, $\mathrm{CH}), 39.2(\mathrm{~m}, \mathrm{CH}), 45.3\left(2 \mathrm{CH}_{3}\right), 50.7\left(\mathrm{CH}_{3}\right), 51.1\left(\mathrm{CH}_{3}\right)$, $66.7(\mathrm{CH}), 117.3(\mathrm{~m}, \mathrm{CH}), 119.8(\mathrm{CH}), 121.8(\mathrm{CH}), 124.7$ $\left(\mathrm{q},{ }^{1} J_{\mathrm{CF}}=273.2 \mathrm{~Hz}, 2 \mathrm{C}_{\mathrm{q}}\right), 126.7\left(\mathrm{~d}, J_{\mathrm{CP}}=41.7 \mathrm{~Hz}, \mathrm{C}_{\mathrm{q}}\right)$, $127.0\left(\mathrm{~d}, J_{\mathrm{CP}}=7.1 \mathrm{~Hz}, \mathrm{CH}\right), 127.9\left(\mathrm{q},{ }^{2} J_{\mathrm{CF}}=32.3 \mathrm{~Hz}, 2 \mathrm{C}_{\mathrm{q}}\right)$, $129.9(\mathrm{CH}), 130.0\left(\mathrm{~d}, J_{\mathrm{CP}}=1.9 \mathrm{~Hz}, \mathrm{CH}\right), 131.7(\mathrm{CH}), 132.4$ $(\mathrm{CH}), 135.1\left(\mathrm{~d}, J_{\mathrm{CP}}=8.6 \mathrm{~Hz}, \mathrm{CH}\right), 135.2\left(\mathrm{C}_{\mathrm{q}}\right), 136.6$ $(2 \mathrm{CH}), 146.7\left(\mathrm{~d}, J_{\mathrm{CP}}=10.1 \mathrm{~Hz}, \mathrm{C}_{\mathrm{q}}\right), 149.9\left(\mathrm{~d}, J_{\mathrm{CP}}=6.7 \mathrm{~Hz}\right.$, $\left.\mathrm{C}_{\mathrm{q}}\right), 153.6\left(\mathrm{C}_{\mathrm{q}}\right), 174.5\left(\mathrm{C}_{\mathrm{q}}\right), 174.9\left(\mathrm{C}_{\mathrm{q}}\right) .{ }^{31} \mathrm{P}$ NMR (121 $\left.\mathrm{MHz}, \mathrm{C}_{6} \mathrm{D}_{6}, 293 \mathrm{~K}\right) \delta 53.2 .{ }^{19} \mathrm{~F}$ NMR $\left(282 \mathrm{MHz}, \mathrm{C}_{6} \mathrm{D}_{6}, 293\right.$ K) $\delta$-61.9. IR (neat) $v$ 2941, 1620, 1498, 1342, 1273, 1120. HRMS (ESI) $\mathrm{m} / z$ Calcd for $\mathrm{C}_{34} \mathrm{H}_{39} \mathrm{~F}_{6} \mathrm{NPPd}$ ([Mmalonate] $]^{+}$): 712.1767; found: 712.1783.

Complex $\mathbf{B}^{2}$. Complex $\mathbf{B}^{2}$ was synthesized according to procedure $\mathrm{B}$ from $\mathbf{A}^{2}$ as the oxidative addition complex. Crystallization was performed in $\mathrm{C}_{6} \mathrm{D}_{6} / n$-hexanes. ${ }^{1} \mathrm{H}$ NMR $\left(300 \mathrm{MHz}, \mathrm{C}_{6} \mathrm{D}_{6}, 293 \mathrm{~K}\right) \delta$ 0.69-0.84 (m, 2H), 0.88-1.05 $(\mathrm{m}, 5 \mathrm{H}), 1.26-1.37(\mathrm{~m}, 3 \mathrm{H}), 1.39-1.61(\mathrm{~m}, 10 \mathrm{H}), 2.00-2.09$ $(\mathrm{m}, 2 \mathrm{H}), 2.36(\mathrm{~s}, 6 \mathrm{H}), 3.19(\mathrm{~s}, 3 \mathrm{H}), 3.26(\mathrm{~s}, 3 \mathrm{H}), 4.86(\mathrm{~s}$, $1 \mathrm{H}), 6.71-6.78(\mathrm{~m}, 2 \mathrm{H}), 6.86-6.90(\mathrm{~m}, 1 \mathrm{H}), 6.98-7.04(\mathrm{~m}$, 2H), 7.09-7.13 (m, 1H), 7.65 (br s, 1H), 7.71 (br s, 2H). ${ }^{13} \mathrm{C}-\left\{{ }^{1} \mathrm{H}\right\}$ NMR (100.6 MHz, $\left.\mathrm{C}_{6} \mathrm{D}_{6}, 293 \mathrm{~K}\right) \delta$ 25.9-28.5 (m, $\left.\mathrm{CH}_{2}\right), 30.9$ (br, $\left.\mathrm{CH}_{2}\right), 37.6$ (br, $\left.\mathrm{CH}\right), 44.1\left(2 \mathrm{CH}_{3}\right), 50.8$ $\left(\mathrm{CH}_{3}\right), 51.0\left(\mathrm{CH}_{3}\right), 66.7(\mathrm{CH}), 117.4(\mathrm{~m}, \mathrm{CH}), 120.2(\mathrm{CH})$, $121.5(\mathrm{CH}), 124.6\left(\mathrm{q},{ }^{1} J_{\mathrm{CF}}=272.8 \mathrm{~Hz}, 2 \mathrm{C}_{\mathrm{q}}\right), 127.3(\mathrm{CH})$, $129.5\left(\mathrm{~d}, J_{\mathrm{CP}}=27.5 \mathrm{~Hz}, \mathrm{C}_{\mathrm{q}}\right), 129.6\left(\mathrm{C}_{\mathrm{q}}\right), 130.2(\mathrm{CH}), 130.9$ $\left(\mathrm{d}, J_{\mathrm{CP}}=10.2 \mathrm{~Hz}, \mathrm{CH}\right), 131.2(\mathrm{CH}), 132.5\left(\mathrm{q},{ }^{2} J_{\mathrm{CF}}=33.9\right.$ $\left.\mathrm{Hz}, 2 \mathrm{C}_{\mathrm{q}}\right), 136.3(2 \mathrm{CH}), 148.6\left(\mathrm{~d}, J_{\mathrm{CP}}=5.9 \mathrm{~Hz}, \mathrm{C}_{\mathrm{q}}\right), 151.1$ $\left(\mathrm{C}_{\mathrm{q}}\right), 174.4\left(\mathrm{C}_{\mathrm{q}}\right), 174.9\left(\mathrm{C}_{\mathrm{q}}\right) .{ }^{31} \mathrm{P}$ NMR $\left(121 \mathrm{MHz}, \mathrm{C}_{6} \mathrm{D}_{6}\right.$, $293 \mathrm{~K}) \delta 30.61 .{ }^{19} \mathrm{~F}$ NMR $\left(282 \mathrm{MHz}, \mathrm{C}_{6} \mathrm{D}_{6}, 293 \mathrm{~K}\right) \delta-61.9$. IR (neat) $v$ 2931, 2854, 1620, 1498, 1342, 1273, 1119. HRMS (ESI) $m / z$ Calcd for $\mathrm{C}_{31} \mathrm{H}_{37} \mathrm{~F}_{6} \mathrm{~N}_{3} \mathrm{PPd}$ ([Mmalonate] $]^{+}$): 702.1670; found: 702.1664 . 
Complex $\mathbf{B}^{\mathbf{3}}$. Complex $\mathbf{B}^{\mathbf{3}}$ was synthesized according to procedure $\mathrm{B}$ from $\mathbf{A}^{3}$ as the oxidative addition complex. Crystallization was performed in $\mathrm{C}_{6} \mathrm{D}_{6} / n$-hexanes. ${ }^{1} \mathrm{H}$ NMR $\left(400 \mathrm{MHz}, \mathrm{CDCl}_{3}, 293 \mathrm{~K}\right) \delta 0.77-0.92(\mathrm{~m}, 2 \mathrm{H}), 0.96-1.29$ $(\mathrm{m}, 5 \mathrm{H}), 1.07\left(\mathrm{~d},{ }^{3} J_{\mathrm{HH}}=6.7 \mathrm{~Hz}, 3 \mathrm{H}\right), 1.19\left(\mathrm{~d},{ }^{3} J_{\mathrm{HH}}=6.7\right.$ $\mathrm{Hz}, 3 \mathrm{H}), 1.34-1.47(\mathrm{~m}, 2 \mathrm{H}), 1.55-1.91(\mathrm{~m}, 10 \mathrm{H}), 1.98-2.13$ $(\mathrm{m}, 2 \mathrm{H}), 2.19-2.31(\mathrm{~m}, 1 \mathrm{H}), 2.71-2.84(\mathrm{~m}, 1 \mathrm{H}), 3.21(\mathrm{~s}$, $3 \mathrm{H}), 3.33(\mathrm{~s}, 3 \mathrm{H}), 4.20(\mathrm{~s}, 1 \mathrm{H}), 7.15-7.21(\mathrm{~m}, 1 \mathrm{H}), 7.28-$ $7.34(\mathrm{~m}, 3 \mathrm{H}), 7.35-7.44(\mathrm{~m}, 5 \mathrm{H}), 7.47-7.52(\mathrm{~m}, 1 \mathrm{H}), 7.54-$ $7.63(\mathrm{~m}, 1 \mathrm{H}) .{ }^{13} \mathrm{C}$ NMR $\left(100.6 \mathrm{MHz}, \mathrm{CDCl}_{3}, 293 \mathrm{~K}\right) \delta 22.5$ $\left(\mathrm{CH}\right.$ or $\left.\mathrm{CH}_{3}\right), 26.2\left(\mathrm{~d}, J_{\mathrm{CP}}=2.6 \mathrm{~Hz}, \mathrm{CH}_{2}\right), 26.8(\mathrm{CH}$ or $\left.\mathrm{CH}_{3}\right), 27.4\left(\mathrm{CH}_{2}\right), 27.6\left(\mathrm{CH}_{2}\right), 27.7\left(\mathrm{CH}_{2}\right), 27.8\left(\mathrm{CH}_{2}\right), 27.9$ $\left(\mathrm{CH}_{2}\right), 30.2\left(\mathrm{CH}_{2}\right), 30.4\left(\mathrm{CH}_{2}\right), 30.6\left(\mathrm{CH}\right.$ or $\left.\mathrm{CH}_{3}\right), 31.5(\mathrm{br}$, $\left.\mathrm{CH}_{2}\right), 36.0\left(\mathrm{~d},{ }^{1} J_{\mathrm{CP}}=23.4 \mathrm{~Hz}, \mathrm{CH}\right), 51.1\left(2 \mathrm{CH}_{3}\right), 65.3$ $(\mathrm{CH}), 117.0(\mathrm{~m}, \mathrm{CH}), 123.9\left(\mathrm{q},{ }^{1} J_{\mathrm{CF}}=272.8 \mathrm{~Hz}, 2 \mathrm{C}_{\mathrm{q}}\right)$, $125.2(\mathrm{CH}), 126.0\left(\mathrm{~d}, J_{\mathrm{CP}}=40.4 \mathrm{~Hz}, \mathrm{C}_{\mathrm{q}}\right), 126.1(\mathrm{CH})$, $126.8\left(\mathrm{~d}, J_{\mathrm{CP}}=8.3 \mathrm{~Hz}, \mathrm{CH}\right), 127.9\left(\mathrm{q},{ }^{2} J_{\mathrm{CF}}=32.3 \mathrm{~Hz}, 2 \mathrm{C}_{\mathrm{q}}\right)$, $129.1(\mathrm{CH}), 129.5\left(\mathrm{~d}, J_{\mathrm{CP}}=2.2 \mathrm{~Hz}, \mathrm{CH}\right), 130.3(\mathrm{CH}), 133.3$ $(\mathrm{CH}), 134.0\left(\mathrm{~d}, J_{\mathrm{CP}}=7.9 \mathrm{~Hz}, \mathrm{CH}\right), 135.5(2 \mathrm{CH}), 139.3(\mathrm{~d}$, $\left.J_{\mathrm{CP}}=3.1 \mathrm{~Hz}, \mathrm{C}_{\mathrm{q}}\right), 145.7\left(\mathrm{~d}, J_{\mathrm{CP}}=8.6 \mathrm{~Hz}, \mathrm{C}_{\mathrm{q}}\right), 147.1\left(\mathrm{C}_{\mathrm{q}}\right)$, $148.1\left(\mathrm{~d}, J_{\mathrm{CP}}=5.3 \mathrm{~Hz}, \mathrm{C}_{\mathrm{q}}\right), 173.9\left(\mathrm{C}_{\mathrm{q}}\right), 174.3\left(\mathrm{C}_{\mathrm{q}}\right) .{ }^{31} \mathrm{P}$ NMR $\left(162 \mathrm{MHz}, \mathrm{CDCl}_{3}, 293 \mathrm{~K}\right) \delta$ 39.9. ${ }^{19} \mathrm{~F}$ NMR $(376$ $\left.\mathrm{MHz}, \mathrm{CDCl}_{3}, 293 \mathrm{~K}\right) \delta-62.5$. IR (neat) $v$ 2935, 2361, $1626,1502,1341,1271,1129$. HRMS (ESI) $\mathrm{m} / z$ Calcd for $\mathrm{C}_{35} \mathrm{H}_{40} \mathrm{~F}_{6} \mathrm{PPd}\left([\mathrm{M} \text {-malonate }]^{+}\right):$711.1814; found 711.1785.

Dimethyl 2-(3,5-bis(trifluoromethyl)phenyl)malonate. ${ }^{16}$ Under argon, a flame-dried Schlenk tube was charged with $\mathrm{CuI}$ (0.05 equiv, $19 \mathrm{mg}, 0.1 \mathrm{mmol})$, 2-phenylphenol $(0.1$ equiv, $34 \mathrm{mg}, 0.0281 \mathrm{~mL}, 0.2 \mathrm{mmol})$, and $\mathrm{Cs}_{2} \mathrm{CO}_{3}(1.5$ equiv, $977 \mathrm{mg}, 3 \mathrm{mmol})$. Then anhydrous THF $(2 \mathrm{~mL}), 3,5-$ bis(trifluoromethyl)iodobenzene (1 equiv, $680 \mathrm{mg}, 0.356$ $\mathrm{mL}, 2 \mathrm{mmol}$ ) and dimethyl malonate (2 equiv, $528 \mathrm{mg}$, $0.457 \mathrm{~mL}, 4 \mathrm{mmol}$ ) were added. The reaction mixture was stirred at $70{ }^{\circ} \mathrm{C}$ for $24 \mathrm{~h}$, and then cooled to room temperature, quenched with a saturated aqueous $\mathrm{NH}_{4} \mathrm{Cl}$ solution, and extracted with ethyl acetate. The organic layer was washed with brine and dried over $\mathrm{MgSO}_{4}$. Filtration through a plug of Celite ${ }^{\circledR}$ and concentration on a rotary evaporator afforded the crude product which was purified by silica gel chromatography (elution with cyclohexane/ethyl acetate 4:1). ${ }^{1} \mathrm{H}$ NMR $\left(300 \mathrm{MHz}, \mathrm{CDCl}_{3}, 293 \mathrm{~K}\right)$ $\delta 3.78(\mathrm{~s}, 6 \mathrm{H}), 4.79(\mathrm{~s}, 1 \mathrm{H}), 7.86(\mathrm{~s}, 1 \mathrm{H}), 7.90(\mathrm{~s}, 2 \mathrm{H}) ;{ }^{13} \mathrm{C}$ NMR $\left(75 \mathrm{MHz}, \mathrm{CDCl}_{3}, 293 \mathrm{~K}\right) \delta 53.4\left(2 \mathrm{CH}_{3}\right), 56.9(\mathrm{CH})$, $123.2\left(\mathrm{q},{ }^{1} J_{\mathrm{CF}}=272 \mathrm{~Hz}, 2 \mathrm{Cq}\right), 122.6(\mathrm{CH}), 130.0(2 \mathrm{CH})$, $132.0\left(\mathrm{q},{ }^{2} J_{\mathrm{CF}}=33 \mathrm{~Hz}, 2 \mathrm{Cq}\right), 135.1(\mathrm{Cq}), 167.4(2 \mathrm{Cq}) \cdot{ }^{19} \mathrm{~F}$ NMR (282 MHz, $\left.\mathrm{C}_{6} \mathrm{D}_{6}, 293 \mathrm{~K}\right) \delta-62.8$; IR (neat) $v 1124$, $1275,1741,2959$. HRMS (ESI) $\mathrm{m} / z$ Calcd for $\mathrm{C}_{13} \mathrm{H}_{10} \mathrm{~F}_{6} \mathrm{NaO}_{4}\left([\mathrm{M}+\mathrm{Na}]^{+}\right): 367.0375$; found 367.0368.

Complex $\mathbf{B}^{4}$. Complex $\mathbf{B}^{4}$ was synthesized according to procedure $\mathrm{B}$ from $\mathbf{A}^{4}$ as the oxidative addition complex. During the synthesis, all vessels were kept at $0{ }^{\circ} \mathrm{C}$. Crystallization was performed in $\mathrm{C}_{6} \mathrm{D}_{6} / n$-hexanes at $0{ }^{\circ} \mathrm{C}$. For characterization purposes, complex $\mathbf{B}^{\mathbf{4}^{\prime}}$ was also synthesized according to procedure $\mathrm{B}$ from $\mathbf{A}^{4}$ as the oxidative addition complex and the potassium salt of dimethyl 2-(3,5bis(trifluoromethyl)phenyl)malonate (5b). ${ }^{1} \mathrm{H}$ NMR $(400$ $\left.\mathrm{MHz}, \mathrm{CDCl}_{3}, 293 \mathrm{~K}\right) \delta 0.64-0.76(\mathrm{~m}, 2 \mathrm{H}), 1.16(\mathrm{~m}, 4 \mathrm{H})$, 1.43-1.56 (m, 4H), 1.59-1.69 (m, 4H), 1.72-1.81 (m, 3H), 1.97-2.09 (m, 3H), 2.16-2.26 (m, 2H), $2.40(\mathrm{~s}, 12 \mathrm{H}), 3.26$ (s, 6H), $6.88(\mathrm{~m}, 2 \mathrm{H}), 7.24(\mathrm{~m}, 1 \mathrm{H}), 7.39$ (br s, 1H), 7.427.47 (m, 1H), 7.48-7.52 (m, 2H), 7.62 (br s, 1H), 7.63 (br s, 2H), 7.77 (br s, 2H), $7.83(\mathrm{~m}, 1 \mathrm{H}) .{ }^{13} \mathrm{C}$ NMR $(100.6 \mathrm{MHz}$, $\left.\mathrm{CDCl}_{3}, 293 \mathrm{~K}\right) \delta 26.2\left(\mathrm{CH}_{2}\right), 27.5\left(\mathrm{CH}_{2}\right), 27.6\left(\mathrm{CH}_{2}\right), 27.7$ $\left(\mathrm{CH}_{2}\right)$, 29.7-30.6 (br, $\left.\mathrm{CH}_{2}\right), 31.8\left(\mathrm{CH}_{2}\right), 35.6-35.9(\mathrm{br}, \mathrm{CH})$, $46.1\left(4 \mathrm{CH}_{3}\right), 51.5\left(2 \mathrm{CH}_{3}\right), 80.6\left(\mathrm{C}_{\mathrm{q}}\right), 115.4(2 \mathrm{CH}), 116.9$ $(\mathrm{m}, \mathrm{CH}), 118.7(\mathrm{~m}, \mathrm{CH}), 123.9\left(\mathrm{q},{ }^{1} J_{\mathrm{CF}}=272.4 \mathrm{~Hz}, 2 \mathrm{C}_{\mathrm{q}}\right)$, $124.0\left(\mathrm{q},{ }^{1} J_{\mathrm{CF}}=272.4 \mathrm{~Hz}, 2 \mathrm{C}_{\mathrm{q}}\right), 126.1\left(\mathrm{~d}, J_{\mathrm{CP}}=9.7 \mathrm{~Hz}\right.$, $\mathrm{CH}), 126.6\left(\mathrm{~d}, J_{\mathrm{CP}}=41.1 \mathrm{~Hz}, \mathrm{C}_{\mathrm{q}}\right), 127.6\left(\mathrm{q},{ }^{2} J_{\mathrm{CF}}=32.3 \mathrm{~Hz}\right.$, $\left.2 \mathrm{C}_{\mathrm{q}}\right), 128.4\left(\mathrm{~d}, J_{\mathrm{CP}}=2.3 \mathrm{~Hz}, \mathrm{CH}\right), 129.7(\mathrm{CH}), 130.2(\mathrm{q}$, $\left.{ }^{2} J_{\mathrm{CF}}=32.3 \mathrm{~Hz}, 2 \mathrm{C}_{\mathrm{q}}\right), 131.1\left(\mathrm{C}_{\mathrm{q}}\right), 132.7(2 \mathrm{CH}), 135.7\left(\mathrm{~d}, J_{\mathrm{CP}}\right.$ $=8.8 \mathrm{~Hz}, \mathrm{CH}), 136.5(2 \mathrm{CH}), 138.1\left(\mathrm{~d}, J_{\mathrm{CP}}=8.1 \mathrm{~Hz}, \mathrm{CH}\right)$, $140.5\left(2 \mathrm{C}_{\mathrm{q}}\right), 143.1\left(\mathrm{~d}, J_{\mathrm{CP}}=6.7 \mathrm{~Hz}, \mathrm{C}_{\mathrm{q}}\right), 146.4\left(\mathrm{~d}, J_{\mathrm{CP}}=6.7\right.$ $\left.\mathrm{Hz}, \mathrm{C}_{\mathrm{q}}\right), 154.3\left(\mathrm{C}_{\mathrm{q}}\right), 170.9\left(2 \mathrm{C}_{\mathrm{q}}\right) .{ }^{31} \mathrm{P}$ NMR $(162 \mathrm{MHz}$, $\left.\mathrm{CDCl}_{3}, 293 \mathrm{~K}\right) \delta 49.3 .{ }^{19} \mathrm{~F} \mathrm{NMR}\left(376 \mathrm{MHz}, \mathrm{CDCl}_{3}, 293 \mathrm{~K}\right)$ $\delta-62.5,-62.6$. IR (neat) $v$ 2937, 1626, 1346, 1273, 1126. HRMS (ESI) $m / z$ Calcd for $\mathrm{C}_{49} \mathrm{H}_{52} \mathrm{~F}_{12} \mathrm{~N}_{2} \mathrm{O}_{4} \mathrm{PPd}\left([\mathrm{M}-\mathrm{H}]^{+}\right)$: 1097.2520; found: 1097.2453.

X-ray Structural Analyses. Suitable crystals were selected and mounted on a Gemini kappa-geometry diffractometer (Agilent Technologies UK Ltd) equipped with an Atlas CCD detector and using Mo radiation $(\lambda=0.7107 \AA)$ except for $\mathbf{B}^{3}$ where $\mathrm{Cu}$ radiation $(\lambda=1.5418 \AA$ ) was used. Intensities were collected at $150 \mathrm{~K}$ for all compounds but $\mathbf{B}^{1}(100 \mathrm{~K})$ and $\mathbf{A}^{\mathbf{1}}(120 \mathrm{~K})$ by means of the CrysalisPro software. ${ }^{17}$ Reflection indexing, unit-cell parameters refinement, Lorentz-polarization correction, peak integration and background determination were carried out with the CrysalisPro software. An analytical absorption correction was applied using the modeled faces of the crystal. ${ }^{18}$ The resulting set of $h k l$ was used for structure solution and refinement. The structures were solved by direct methods

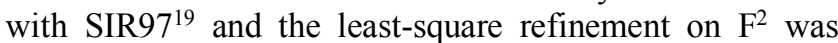
achieved with the CRYSTALS software. ${ }^{20}$ All nonhydrogen atoms were refined anisotropically. The hydrogen atoms were all located in a difference map, but those attached to carbon atoms were repositioned geometrically. The $\mathrm{H}$ atoms were initially refined with soft restraints on the bond lengths and angles to regularize their geometry (C---H in the range 0.93--0.98, N---H in the range 0.86-0.89 and $\mathrm{O}---\mathrm{H}=0.82 \AA$ ) and $\mathrm{U}_{\text {iso }}(\mathrm{H})$ (in the range 1.2-1.5 times $\mathrm{U}_{\mathrm{eq}}$ of the parent atom), after which the positions were refined with riding constraints. Complex $\mathbf{A}^{\mathbf{3}}$ displayed solvent accessible voids of $102 \AA^{3}$ in the unit-cell were residual electronic density was present. The contribution of the disordered solvent was removed using the SQUEEZE algorithm. ${ }^{21}$

\section{ASSOCIATED CONTENT}

Supporting Information.

NMR spectra and X-ray crystallographic data (CIF) of all complexes, DFT calculations (Scheme 2). This material is available free of charge via the Internet at http://pubs.acs.org.

\section{AUTHOR INFORMATION}




\section{Corresponding Authors}

*E-mail: olivier.baudoin@unibas.ch Notes

The authors declare no competing financial interest.

\section{ACKNOWLEDGMENT}

We thank Ministère de l'Enseignement Supérieur et de la Recherche and Institut Universitaire de France for financial support, Johnson Matthey PLC for a loan of palladium salts, and CCIR-ICBMS (Université Claude Bernard Lyon 1) for the allocation of computational resources. We are also grateful to E. Jeanneau (Centre de Diffractométrie Henri Longchambon, UCBL) for X-ray diffraction analyses.

\section{REFERENCES}

(1) Mahatthananchai, J.; Dumas, A. M.; Bode, J. W. Angew. Chem. Int. Ed. 2012, 51, 10954.

(2) (a) Renaudat, A.; Jean-Gérard, L.; Jazzar, R.; Kefalidis, C. E.; Clot, E.; Baudoin, O. Angew. Chem. Int. Ed. 2010, 49, 7261. (b) Larini, P.; Kefalidis, C. E.; Jazzar, R.; Renaudat, A.; Clot, E.; Baudoin, O. Chem.-Eur. J. 2012, 18, 1932. (c) Aspin, S.; Goutierre, A.S.; Larini, P.; Jazzar, R.; Baudoin, O. Angew. Chem. Int. Ed. 2012, 51, 10808. (d) Aspin, S.; López-Suárez, L.; Larini, P.; Goutierre, A.-S.; Jazzar, R.; Baudoin, O. Org. Lett. 2013, 15, 5056.

(3) (a) Barder, T. E.; Walker, S. D.; Martinelli, J. R.; Buchwald, S. L. J. Am. Chem. Soc. 2005, 127, 4685. (b) Barder, T. E. J. Am. Chem. Soc. 2006, 128, 898. (c) Barder, T. E.; Biscoe, M. R.; Buchwald, S. L. Organometallics 2007, 26, 2183. (d) Barder, T. E.; Buchwald, S. L. J. Am. Chem. Soc. 2007, 129, 12003. (e) Ikawa, T.; Barder, T. E.; Biscoe, M. R.; Buchwald, S. L. J. Am. Chem. Soc. 2007, 129, 13001.

(4) (a) Seel, S.; Thaler, T.; Takatsu, K.; Zhang, C.; Zipse, H.; Straub, B. F.; Mayer, P.; Knochel, P. J. Am. Chem. Soc. 2011, 133, 4774. (b) Millet, A.; Larini, P.; Clot, E.; Baudoin, O. Chem. Sci. 2013, 4, 2241. (c) Millet, A.; Dailler, D.; Larini, P.; Baudoin, O. Angew. Chem. Int. Ed. 2014, 53, 2678.

(5) Reviews on biarylphosphine ligands: (a) Martin, R.; Buchwald, S. L. Acc. Chem. Res. 2008, 41, 1461. (b) Surry, D. S.; Buchwald, S.
L. Angew. Chem. Int. Ed. 2008, 47, 6338. (c) Surry, D. S.; Buchwald, S. L. Chem. Sci. 2011, 2, 27.

(6) Old, D. W.; Wolfe, J. P.; Buchwald, S. L. J. Am. Chem. Soc. 1998, 120,9722

(7) Wolfe, J. P.; Singer, R. A.; Yang, B. H.; Buchwald, S. L. J. Am. Chem. Soc. 1999, 121, 9550.

(8) (a) Han, C.; Buchwald, S. L. J. Am. Chem. Soc. 2009, 131, 7532. (b) Yang, Y.; Niedermann, K.; Han, C.; Buchwald, S. L. Org. Lett. 2014, 16, 4638.

(9) Clot, E.; Mégret, C.; Eisenstein, O.; Perutz, R. N. J. Am. Chem. Soc. 2009, 131, 7817.

(10) (a) Fors, B. P.; Watson, D. A.; Biscoe, M. R.; Buchwald, S. L. J. Am. Chem. Soc. 2008, 130, 13552. (b) Watson, D. A.; Su, M.; Teverovskiy, G.; Zhang, Y.; García-Fortanet, J.; Kinzel, T.; Buchwald, S. L. Science 2009, 325, 1661. (c) Maimone, T. J.; Milner, P. J.; Kinzel, T.; Zhang, Y.; Takase, M. K.; Buchwald, S. L. J. Am. Chem. Soc. 2011, 133, 18106. (d) Su, M.; Buchwald, S. L. Angew. Chem. Int. Ed. 2012, 51, 4710. (e) Milner, P. J.; Maimone, T. J.; Su, M.; Chen, J.; Müller, P.; Buchwald, S. L. J. Am. Chem. Soc. 2012, 134, 19922.

(11) (a) Kocovsky, P.; Vyskocil, S.; Cisarova, I.; Sejbal, J.; Tislerova, I.; Smrcina, M.; Lloyd-Jones, G. C.; Stephen, S. C.; Butts, C. P.; Murray, M.; Langer, V. J. Am. Chem. Soc. 1999, 121, 7714. (b) Faller, J. W.; Sarantopoulos, N. Organometallics 2004, 23, 2008.

(12) Torborg, C.; Huang, J.; Schulz, T.; Schäffner, B.; Zapf, A.; Spannenberg, A.; Börner, A.; Beller, M. Chem.-Eur. J. 2009, 15, 1329.

(13) Culkin, D. A.; Hartwig, J. F. J. Am. Chem. Soc. 2001, 123, 5816.

(14) Wolkowski, J. P.; Hartwig, J. F. Angew. Chem. Int. Ed. 2002, $41,4289$.

(15) Pan, Y.; Young, G. B. J. Organomet. Chem. 1999, 577, 257.

(16) Hennessy, E. J.; Buchwald, S. L. Org. Lett. 2002, 4, 269.

(17) CrysAlisPro, Agilent Technologies, Version 1.171.37.33 (release 27-03-2014 CrysAlis171.NET) (compiled Mar 27 2014,17:12:48).

(18) Clark, R. C.; Reid, J. S. Acta Cryst. 1995, A51, 887.

(19) Altomare, A.; Burla, M.C.; Camalli, M.; Cascarano, G. L.; Giacovazzo, C.; Guagliardi, A.; Grazia, A.; Moliterni, G.; Polidori, G.; Spagna, R. J. App. Cryst. 1999, 32, 115.

(20) Betteridge, P. W.; Carruthers, J. R.; Cooper, R. I.; Prout, K.; Watkin, D. J. J. Appl. Cryst. 2003, 36, 1487.

(21) Sluis, P. v. d. ; Spek, A. L. Acta Cryst. 1990, A46, 194. 
Table of Contents Graphic:

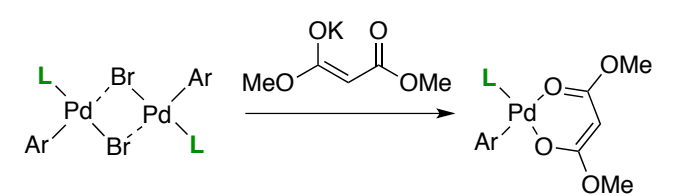

$\mu$-bridged dimer or monomer $\quad \kappa^{2}$ malonate complex

$\mathrm{L}=\left\langle\mathrm{Ar}>\begin{array}{l}\mathrm{Ar}=\mathrm{Ph}, \text { imid } \\ \mathrm{R}^{1}=\mathrm{NMe}_{2}, \mathrm{i}-\mathrm{Pr} \\ \mathrm{R}^{2}=\mathrm{H}, \mathrm{NMe}_{2}\end{array}\right.$ 